Policy Research Working Paper 1660

Mind Your P's and Q's

The Cost of Public Investment is Not the Value of Public Capital

Lant Pritchett
A dollar's worth of public investment spending often does not create a dollar's worth of capital, especially in developing countries. One deep difficulty of development may be that even when public capital is productive it may be difficult to create this capital in the public sector.

The World Bank

Policy Research Department

Poverty and Human Resources Division

October 1996 


\section{Summary findings}

Pritchett presents theory and calculations to show that part of the explanation of slow growth in many poor countries is not that governments did not spend on investments, but that these investments did not create productive capital. For a variety of reasons, governments take resources from current consumption to "invest" in the economic equivalent of pyramids, items that produce no future output.

The most critical assumption (of the many) necessary for cumulated investment flows to be even reasonable proxies for capital stocks is that the cost of investment (the $p$ 's) is equal to the value of the capital stock evaluated as its increment to future profitability (the q's). This assumption can be justified only if investors act to equalize these - and under many conditions, profitmaximizing investors will do so. But there is ample reason not to believe that all governments act as profitmaximizing investors - and ample reason to believe that some governments invest better than others.

The implication, especially in developing countries, is that a dollar's worth of public investment spending often does not create a dollar's worth of public capital. A variety of calculations suggest that in a typical developing country less than 50 cents of capital were created for each public dollar invested. One of the deep difficulties of development may well be that even when public capital is productive it may be difficult to create this capital in the public sector.

This paper - a product of the Poverty and Human Resources Division, Policy Research Department - is part of a larger effort in the department to investigate the impact of policies on long run economic growth. Copies of the paper are available free from the World Bank, $1818 \mathrm{H}$ Street NW, Washington, DC 20433. Please contact S. Fallon, room N8-030, telephone 202-473-8009, fax 202-522-1153, Internet address sfallon@worldbank.org. October 1996. (49 pages)

The Policy Research Working Paper Series disseminates the findings of work in progress to encourage the exchange of ideas about development issues. An objective of the series is to get the findings out quickly, even if the presentations are less than fully polished. The papers carry the names of the authors and should be used and cited accordingly. The findings, interpretations, and conclusions are the authors' own and should not be attributed to the World Bank, its Executive Board of Directors, or any of its member countries. 


\title{
Mind your p's and q's: \\ The cost of public investment is not the value of public capital
}

\author{
Lant Pritchett
}





\section{Mind your p's and q's:}

\section{The Cost of Public Investment is not the Value of Public Capital ${ }^{1}$}

Two metaphors illustrate the central problems with the valuation of public sector capital. The first is the tale of two country's steel mills. Both mills were built by parastatals with government backing with investments of several billion dollars. One mill is now a model of efficiency and a serious competitor in world steel markets while the other has yet to produce a single ton of steel. Obviously the value of the two steel mills is very different, yet according to usual growth accounting methods the "capital" of these two firms is similar.

A second metaphor has to do with types of investment. Compare two types of investments that create fixed structures; building pyramids and digging canals. Suppose one country invests only in canals, which increase output, while in another country a tyrant memorializes himself by spending the same amount on fixed structures, but builds only pyramids. Again, if the government's "investments" were added up over time the two countries would have similar stocks of public sector "capital."

Imagine that in the middle of either of these stories a researcher stumbles in and proposes to answer the question of the productivity of public capital. The researcher will likely find that the average impact of public sector investments across countries is quite small. From this empirical finding one might be tempted to recommend that the public sector should

1 I would like to thank Bill Easterly, Deon Filmer, Jonah Gelbach, Aart Kray, Ross Levine, Norman Loayza, Allison Morantz. Moshe Syrquin, Vinaya Swaroop, Mike Walton and the participants at seminars at the World Bank and the Council of Economic Advisors for useful comments and discussions. 
invest less since the productivity of public capital is low. This recommendation is clearly not correct. But what went wrong methodologically? The researcher merely assumed what every other researcher does; that investments measured at their cost, the price the investor must pay to attract the resources, create an equivalent increase in the value of capital. But if the value of the capital stock is defined as the increment to future profitability, then it is obvious that the excess costs of steel mill construction or investments in pyramids (irrespective of their cost) create no capital.

In order to make sensible policy recommendations about public investments three parameters need to be identified: the potential productivity of public capital, the efficacy of public investments in creating public capital from resources invested, and the expected efficiency of the public sector in operating capital. Policy discussions about whether governments should "do more" or "do less" depend not only on the potential effect of government action in the abstract but also on an assessment of what any given government will actually $\mathrm{do}^{2}$. Policy recommendations clearly must differ across countries, as a country with a less effective government would have to have a higher productivity of public capital to justify public investment than another country with a more effective public sector.

The first section of the paper formalizes the metaphors. The second section gives several examples, both positive and negative, of ways in which actual governmental behavior

2 The distinction is often seen between those researchers that emphasize the "market failures" or social inequities that create a potential for a social welfare maximizing planner. Some argue on the basis of a potential welfare improvement by a hypothetical welfare maximizer to an proposal for some real action by an actual government. In contract, other researchers emphasize the (pehaps intrinsic) failings in how governments do in fact behave. 
will determine the efficacy of investment in creating public (and private) capital. The third section uses micro evidence to estimate how empirically important this particular effect might be, and tries to draw the (empirically difficult) distinction between public investment that does not really create public capital and public capital not effectively used once created. The fourth section reinterprets the data on macroeconomic growth, factor accumulation, and total factor productivity to suggest that as much as one half of investment in some LDC regions was not productive. The fifth section shows how this approach to the question of the valuation of capital is useful by using it to interpret the existing empirical results on public sector investment and discusses policy recommendations that flow from this approach.

\section{What is the value of the stock of productive capital?}

The metaphors in the introduction are contrived to illustrate a critique of comparing investment spending across countries that goes very deep. Without specific behavioral assumptions about the motivations of investors nothing can be inferred about the economic productivity of various types of investments from existing data. The problem of distinguishing productive (canals) versus non-productive (pyramids) investments is not simple. Within every government sector there are both non-productive investments undertaken for non-economic reasons (pyramids) and productive investments (canals). Sectoral examples are useful in making ideas concrete (but may only reveal my biases). For instance, within the health sector there are expenditures on basic public health measures (canals) and there are chrome plated 
urban hospitals (pyramids) ${ }^{3}$, within education there are primary schools (canals) and there are free universities (pyramids). The critique goes even deeper than comparisons of different items within sectors as even within any sector expenditures on exactly the same item, say, roads, may link critical markets and be tremendously productive (canals) or may lead nowhere but the national leader's summer palace (pyramids). Even real canals may be metaphorical pyramids, as in many cases irrigation projects are undertaken in an excessively capital intensive manner that ignores local conditions and allocation mechanisms of existing water and have little or no payoff in increased productivity (pyramids) while other real canals are metaphorical canals (Ostrom, 1995). The critique goes deeper still, because even in building the productive canals (canals) various types of public sector malfeasance may lead to higher than necessary costs (partial pyramids).

\section{A) The value of capital}

The history of economic thought about "capital" is long and tortured and I am hoping to duck most of the issues to make what is, I think, a simple point 4 . That point is that with the usual, but very restrictive, assumptions the cost of investment and value of capital created by

${ }^{3}$ When I say "public health" I do not mean "primary health care" I mean the provision of those (few) health services which are public goods.

4 In has long been recognized that the idea of a single aggregate called "capital" as a determinant of economic outcomes is problematic as the value of capital cannot be defined independently of the structure of relative prices, and in particular, interest rates. The CambridgeCambridge controversies on the use of "capital" as a determinant of the interest rates being the perhaps most famous example of the problems. 
that investment will be equated $e x$ ante by profit maximizing investors ${ }^{5}$. However, when the objective function of an investor, such as a government, is not profit maximization, then there is absolutely no reason to expect the cost of those expenditures classified as "investments" and the value of capital created by those expenditures to coincide even ex ante.

Say there are goods 1 to $\mathrm{N}$ in the economy and time is indexed by $\mathrm{t}$ up to $\mathrm{T}$ periods and $\mathbf{X}$ is the ( $\mathrm{N}$ by $\mathrm{T}$ ) matrix which is the net consumption of good $\mathrm{n}$ in period $\mathrm{t}$ (outputs are positive). In this set-up a capital good is a good which is an input into the production of other goods and which is not fully exhausted in a single period. The actual cost of creating the capital good is the discounted sum of the purchased inputs. There are two points. First, the cost of a capital good depends only on past (the "P's" of the title) not future prices. Second, this is actual cost, not economic cost. Economic cost is defined as the minimum of possible actual costs subject to the technological constraints that the inputs can produce the output (line 2 of table 1). When I say "cost" I mean the cost, not the minimum cost.

SIt has long been well known that cost of investment and the value of capital are not linked ex post. Among the many antecedents of the distinguishing the cost of investment from the value of capital is Hayek's The Pure Theory of Capital (1941). He cites two very harmful ideas to the theory of capital, one of which is:

that particular capital items represented a definite value, independently of the use that could be made of them, a value which was apparently thought to be determined by the amounts 'invested' in them. (p. 10). 


\begin{tabular}{|c|c|c|}
\hline 1 & $\begin{array}{l}\text { Cost, the actual cost of } \\
\text { creating the capital good }\end{array}$ & $C\left(p, X_{-1}, K\right)=\sum_{k=-K}^{k=0} \delta^{k} * p_{t-k}^{\prime} X_{-1, t-k}$ \\
\hline 2 & $\begin{array}{l}\text { Economic Cost, the } \\
\text { minimum cost necessary } \\
\text { to create the capital good. }\end{array}$ & $\begin{aligned} E C\left(p, X_{1, l}\right)= & \min C\left(p, X_{-1}, K\right) \\
& \text { s.t. } g\left(X_{-1, t-K}, \cdots, X_{-1, t}\right)=X_{1}, t\end{aligned}$ \\
\hline \multicolumn{3}{|c|}{ Various concepts of the valuation of capital } \\
\hline 3 & $\begin{array}{l}\text { "Constrained" value of } \\
\text { capital, the current net } \\
\text { present value of the } \\
\text { contribution to output of } \\
\text { capital good } \mathrm{X}_{1, \mathrm{~T}} \text { when } \\
\text { inputs and outputs are } \mathrm{X}_{-1} \\
\text { (not necessarily } \\
\text { optimizing) valued at } \\
\text { price p }\end{array}$ & $C V\left(X_{1, \Gamma} X_{-1}, p\right)=\sum_{i=T}^{=-\Gamma} \delta^{t} * R_{t}\left(X_{1, T} X_{-1}, p\right)$ \\
\hline 4 & $\begin{array}{l}\text { "Market" value of } \\
\text { capital, the current } \\
\text { maximal net present } \\
\text { value of the contribution } \\
\text { of the capital good } X_{1, \delta} \text { to } \\
\text { output valued at } p\end{array}$ & $V\left(X_{1, T}, p\right)={ }_{X_{-1}}^{\max } C V\left(X_{1, T} X_{-1}, p\right)$ \\
\hline 5 & $\begin{array}{l}\text { "Optimal" value of } \\
\text { capital, the current } \\
\text { maximal net present } \\
\text { value of the contribution } \\
\text { of the capital good } X_{1,1} \text { to } \\
\text { output when prices are } \\
\text { set optimally to } \mathrm{p}^{*}\end{array}$ & $V\left(X_{1, \Gamma} p^{\circ}\right)$ \\
\hline & $\mathrm{X}$ is an $\mathrm{N}$ (good) by $\mathrm{T}$ & iod) matrix of netputs. \\
\hline
\end{tabular}

What is the value of a capital good? I define the "market" value of the capital good as its maximum possible (when inputs and outputs are chosen optimally) increment to the net 
present value of future output (line 4). There are layers and layers in this definition, but three points should be emphasized. First, the definition of the value of capital depends on maximizing behavior. Just as with costs, one could define the a constrained value of capital as the actual future increment to profits for a given set of inputs and outputs, where those inputs are not necessarily chosen optimally (e.g. when parastatals are over staffed, or requisite inputs not available). This "constrained value" of capital need not even be positive (say adding a machine brings a requirement to add 3,000 excess workers). While it is reasonable to define the value of capital as the maximized value, in many cases the benefit flow from a given capital stock will not be maximized, particularly by public sector entities. Second, the value of capital has absolutely nothing to do with past prices. Only the future matters for the value of capital. Sunk costs are sunk. Third, under some conditions, profit maximizing investors will choose to equate, at a point in time, the cost of investment and the value of capital, as defined here ${ }^{6}$. However, this in turn depends on at least two things: a) a particular positive theory of investor behavior and b) that the incremental value produced by the capital good can be captured by the owners. This is why "market" value is in quotes, as I want to have a “market" value defined even for capital goods that produce public goods.

Another concept is the value of a capital good at the prices that would prevail under the best set of government policies (line 5). These prices are not necessarily market prices, as the best set of policies involves a variety of empirical conclusions about the magnitude of things

${ }^{6}$ Moreover, this equation of cost of investment and value of capital will only be true at a point in time. Unanticipated shocks can potentially cause large changes in the value of capital while not changing the (historical) cost of investment. 
that actually involve optimal interventions to force prices away from market prices:

externalities, learning spillovers, capital market constraints, etc. As an empirical matter the actual pattern of prices induced by the existing set of government interventions is highly unlikely to be the optimal. The "market" value of capital could be evaluated at any particular set of prices; actual prices, at the prices that would prevail under laissez faire, prices under free trade, or at fully "optimal" prices.

Since the value of capital depends on future prices, changes in relative prices will bring changes in the value of capital goods. Large changes in the value of (private or public) capital are possible after economic reform, as profit maximizing investors will have created a capital stock that responds to distorted price incentives.

Each of the concepts: actual cost of investment, economic cost of investment, constrained value of capital, market value of capital, and optimal value of capital, points to a way in which the same cost of investment in the past has created different amounts of current capital. First, actual costs, especially of government investments, may have been larger that the economic cost. Second, price shifts may have changed the value of capital relative to its economic cost. Third, the constrained value of capital, again especially in the public sector, may be smaller than its maximal value. Fourth, the market value at prevailing prices (including whatever distortions may exist) may be larger than the value of the same physical capital stock evaluated at optimal prices.

\section{B) The productivity of capital versus the efficacy of investment}

The distinction between the efficacy of investment spending (the ratio of economic to 
actual cost) in creating capital and the productivity of capital is important particularly for understanding the ability of empirical work to investigate the impact of public capital on output. Say we take a simple production function specification that distinguishes private and public capital stocks:

$$
Y=A * K_{i}^{\alpha} \cdot * K_{\varepsilon}^{\alpha_{\epsilon}}
$$

Now suppose that only a fraction $\gamma($.$) of public investment actually creates useful public$ capital ${ }^{7}$ :

$$
\hat{K}_{\varepsilon}=\gamma(.) *(I / Y) *\left(Y / K_{\varepsilon}\right)-\delta_{\varepsilon}
$$

When this definition of capital growth is substituted into the expression for growth rates of output the coefficient on public investment in the growth equation is the product of the production function parameter $\left(\alpha_{z}\right)$ and the efficacy of investment coefficient $\gamma()$ :

$$
\hat{y}=\alpha_{c} *\left(\gamma(.) * \frac{I_{c}}{Y}-\delta_{c}\right)+\alpha_{;} *\left(\frac{I}{Y}-\delta_{;}\right)+\hat{A}
$$

A growth regression (or any other empirical procedure) that was limited to observing outputs and investment inputs cannot separately identify the two effects ${ }^{8}$.

7 The usual perpetual inventory methods simply assume that the fraction of investment into capital $(\gamma)$ is 1 . For an application of the approach to US federal government investment data see Boskin, Robinson, and Roberts (1985).

- One way to see this is as a measurement problem of capital stock growth because the investment expenditures are not appropriately deflated, which is valued analytically as then 
This is not an a problem of estimation of the regression coefficients but of their interpretation. This is not a problem of bias in the estimate of the productivity of public capital $\left(\alpha_{\mathfrak{z}}\right)$ but of identification, which is much more serious. Bias (or inconsistency) means that parameter estimates not centered on its true value, but identification is means one doesn't really have an estimate of the parameter at all. Assume that $\gamma$ (the efficacy of investment) were fixed across all countries. Then coefficient on public investment from a growth regression is not a biased estimate of the productivity of public capital but rather is a (perhaps biased) estimate of $\gamma^{*} \alpha_{g}$.

Of course, the effectiveness of public investment $\gamma($.$) is not a fixed parameter, but$ varies across countries as the the endogenous outcome of some process. Assume the determinants of efficacy were known, say for simplicity it was determined completely by some variable $\mathrm{Z}$. It is still the case that the regression of growth on investment recovers $\bar{\gamma}(z) * \alpha_{c}$ (the output effect of investment evaluated at average efficacy) but not $\alpha_{g}$. This is not an issue about omitted variables bias, as inserting $\mathrm{Z}$ (or some additional variables thought to be related to government efficicacy) into the growth regression does not solve the identification problem. This is also not an issue of the specification of how public capital enters into the production function, but of the correct definition of the growth of public capital

government investments would simply be imputed at their "economic" not actual cost. This however is not practicable with the data at hand. First, this is not a matter of the "price" of capital in the sense of the minimum price at which "capital" goods can be purchased but the deviation of "costs" from "prices". Second, since the efficacy may well come in the combination of factors the "price" of the inputs may be mismeasured. Third, if we could measure the "price" it would look like the value in which case we wouldn't need to worry about the price. 
stock. Even if country specific efficacy were completely observable, a linear regression of growth on public investment and efficacy (and whatever other terms) does not recover an estimate of the productivity impact of public capital. Similarly, different production function specifications than the simple Cobb-Doubglas above, as for instance entering in public capital as enhancing the productivity of private capital, will not change the fact that public investment does not measure public capital growth and hence cannot be used as its proxy in any form of production function one would care to postulate?

An empirical finding that "public investment" is not related to performance can either mean that a) countries have over-invested in public capital so its marginal product $\left(\alpha_{q}\right)$ is very low or b) that public capital is very productive but that the average effectiveness of public investment in creating public capital $(\gamma)$ is very low or $c)$ that public capital has been created effectively but used badly or d) any combination of the three. While it is the case that the coefficient on investment gives an estimate of the average effect of government investment over the particular sample, if one wants to invest when the returns to investment are high (higher say that than the opportunity cost of funds) then one needs to know both $\gamma$ and $\alpha_{8}$ for the specific country under consideration not the average (that is, unless one chooses to act as if one is completely uninformed about country conditions). Moreover, if $\gamma$ is low then the most desirable policy decision may be to attempt to raise the efficacy before expanding investment. Hence, much of the discussion about the public sector and its reform is focused not on the

9 Just because I use a "Solow" type production function for the example, this is not a "new" versus "old" growth issue or a "spillovers" verus "direct productivity" issue or anything other issue about the assumed production function. One way or another "public capital" will enter the production function and this is about what that will look like. 
correct magnitude of investment, but around how to change the system of incentives within the public sector to increase effectiveness ${ }^{10.11}$.

\section{II._Minding p's and q's}

Most economists' intuition about capital are based on what profit maximizing investors do. Profit maximizing investors will be cost minimizers so that, on average, actual costs will be equated with economic costs. Moreover, if there is a market for capital, this will tend to equate constrained with market value (as inefficient users of capital are bought out or decline as a share of the market). However, no one believes that all governments in the world behave as profit maximizing investors and worse, there is no universally accepted positive theory of how governments behave, either as investors or otherwise. There are good reasons for this lack of consensus ${ }^{12}$. I am not going to attempt a positive theory that attempts to explain the

10 This common feature of focus on public sector incentives links many current strands of development literature, including: talk of "governance" and "accountability," the treatment of infrastructure in the 1994 World Development Report (which focused on the internal organization of infrastructure providers), the talk of "reinventing government" in the USA (Osborne and Gaebler, 1992), discussions of participation as a means of improving public performance (Isham, Narayan, and Pritchett, 1995), estimates of the relationship between returns on investment and civil liberties (Isham, Kaufmann, and Pritchett, 1996) and the work on the features of the public sector in East Asia (Campos and Root, 1996).

"Distinct from the "public sector effectiveness" literature is that which emphasizes "institutional" features that effect both public and private investments. For instance, the emphasis of Olson's (1996) explanation of income level differences is not so much on why there is no investment as to why what investment there has been has not created economic growth.

12 Even if it could be assumed that all government behavior could be understood as the result of the choices of a unitary actor (which it can't), and even if all those unitary actor governments had the same objective function (which they don't), governments will face different institutional arrangements and hence will differ substantially in their observed 
cross national differences in the efficacy of investment, merely point out some examples of such behavior.

Venality. Government officials often receive direct money payments for the granting of contracts for investment projects (or other government purchases) ${ }^{13}$. To the extent that the payment of bribes does not reduce the profits of the supplier, bribes for acquiring the contract will be part of the cost of investment. This type of corruption will drives a wedge, B, between the actual cost of an investment project ( $x$ ) and its economic cost.

$$
C(x)=E C(x)+B
$$

B is not just the bribe but all higher costs associated with the venality (since the very fact of concealing the bribe may create higher costs which do not accrue directly either to the payer or to the receiver of the bribe). This venality cost (B) creates a wedge between the cost of investment and the value of capital. The government could not sell the newly created capital to an investor for what they paid for it, but at most for its economic cost.

Lack of government efficiency in investment. Even without venality government

behavior. Crudely put, even if a dictator and an elected president had as their only objective personal enrichment they would face very different constraints in achieving this objective.

13 I am not working out a positive theory of corruption, only the implications of its existence for the valuation of investment. Why it is that, among its many manifestations, corruption takes the form of a share of investment contracts I can only speculate. There are several reasons why investment projects might be a particularly attractive source of corruption opportunities. One is that the complexity of the transaction makes it more difficult to identify the corruption since in many cases the goods being procured are unique it is more difficult to assess their fair market value. Another is that since investment contracts are given out in large chunks it may be more convenient to extract the rents at that stage. 
agencies may be less effective at cost minimizing in the creation of capital that the private sector. This relative efficacy may well be due to intrinsic constraints in creating incentives when the residual claimant is not well defined. Again, the capital created by a government entity could not sell for what it cost to create.

Aid financed investments. Another set of investments which are unlikely to be cost minimizing are government projects financed by external aid. In many cases the bilateral donors are willing to finance projects at concessional rates of particular types produced by export interests in the donor country. In this case the government may well choose a substantially more expensive project in terms of cost because the net cost to the government is lower. Or, alternatively, the donor's willingness to finance capital cost may lead the government to choose excessively capital intensive projects. On a deeper incentives level, typically neither the staff of the donor agency nor of the implementing government have equity stakes in their projects so cost minimizing incentives are few. Nevertheless, in all these cases the actual, not economic, cost is recorded as investment.

Patronage. Another example is when the location and magnitude of investments are subject of political considerations about the conventionally known is "patronage". This is different from the case of venality, in that the government official does not directly derive private benefits and no established laws or norms are broken. In this case either the amount spent may well be higher than if resources were allocated optimally or characteristics of the investment are different. Again in the case these impacts are thought to be large as journalistic accounts of public sector investment decisions (in developed as well as developing countries) over location are replete with examples of steel plants far from input sources, factories far 
from transport, etc.

Poverty aversion. Examples of deviations of government decisions from profit maximization need not be "negative." Any deviation of the government's objective function from profit maximization at market prices will suffice. For instance, one way in which the government investment valued at cost could differ from its increment to productive capital at market prices is if the government systematically pursues projects that benefit the poor. A government may use distributionally weighted economic rates of return rather than financial rates of return in making investment decisions. In this case a given increment of investment will not produce large increments to output evaluated at market prices, but may produce a larger increment to social welfare or equivlanently, to output evaluated as some set of "shadow" prices.

This is not to argue that government investment is everywhere and always inefficient. However, there are difficulties is structuring the incentives of the public sector decision makers responsible for investments such that they produce capital. This incentive problem is present whenever ownership and management are separate. However, the public sector does differ in important respects from private organizations in ways that make the problem of creating the right incentives in the public sector qualitatively more difficult ${ }^{14}$.

${ }^{14}$ First, the state, by definition, exercises coercive power (e.g., police, judiciary and military) towards its citizens. Now while the use of this power is more or less restricted through a variety of mechanisms it does imply that "the state." unlike a private firm, necessarily retains the ability to extract investible funds irrespective of the investors (taxpayers) views of the profitability of the capital to be created.

Second, because two entities claiming coercive power over the same territory is called "war" the state is generally a monopoly. This intrinsic monopoly implies that monitoring is difficult because of the difficulty of making direct comparisons. The intrinsic monopoly also 


\section{A) The p's and g's of private sector investment in distorted environments}

From the above section one may have the impression that if one could separate in the data private investment from public investment then at the least cumulated flows of private investment could be used to investigate the productivity of private capital. However, this is not completely true, even ignoring the problems of agency within the private sector ${ }^{15}$. I'll give three examples.

Private investments with government (or government guaranteed) financing. Often the public sector lends money to agents in the private sector (either directly or through a parastatal bank). This creates at least three possibilities for investment-capital divergence. First, the government may deliberately subsidize lending for particular investments (by sector, by region). In this case even though the investments are in the private sector, they have the same potential divergence between cost and value of capital as in the patronage case. Second, in many cases the financing provided by public entities for "private" investment was not repaid and in many of those cases this defaulr was anticipated by both borrowers and the lenders.

implies that new start-ups are not a viable mechanism for responding to ineffective states. Hence management changes in many cases require the use of force: hostile takeovers of governments tend to be very hostile.

Third, with governments, unlike corporations, the claims to the residual value of assets are not traded. Anyone disgruntled with the management of GM can use an "exit" option and sell her claim to someone else. This provides a useful signal and monitoring of management performance at creating shareholder value. Citizenship on the other hand is typically not for sale. "Voice" remains the only option for expressing discontent with government's investment performance and the degree to which "voice" can be effective varies

is In the corporate sector managers benefit more than shareholders from certain types of investment and hence may manipulate investment. This agency problem within corporations has received a great deal of attention in the business literature. A recent study suggested that nearly all of the investments of GM over the last decade did not create any shareholder value (capital). 
There is no small amount of collusive behavior between private individuals which borrow from public entities for "investments" which are fictitious. Third, when there are public guarantees of the depositors there is a huge incentive for collusion between bankers and borrowers ${ }^{16}$.

Private investments in a distorted environment. The second way in which government policies affect the value of private investments is through policy distortions. For instance, when the government imposes a tariff and raises the relative domestic price of a good. This potentially attracts more investment into that sector than in the absence of the tariff. This creates a divergence between the value of the private capital stock at actual and at optimal relative prices ${ }^{17}$. If there is subsequently a reform then the existing capital stock will be revalued ${ }^{18}$

Terms of trade shocks, creative destruction, and revaluations of investment. The final

${ }^{16}$ Akerlof and Romer (1993) discuss a similar phenomena of private "looting." They argue that a large fractions of the loans given the US S\&Ls for instance, although they nominally were for investments, were really ways of pumping money to S\&L owners through incredibly risky investments with low probabilities of pay-off, but which left losses to be recovered by the government.

17 These considerations are related to the conceptual value of capital. In addition there are serious measurement issues in the data that are associated with large distortions. For instance, when exchange rates are overvalued there are incentives to over-invoice imports. Since in many cases one element of the estimate of aggregate private investment is the imports of capital goods, this over invoicing will cause investment to be overstated.

18 This obviously has been a major issue in the transition in Eastern Europe. Many large assets that were geared to producing for the centrally planned domestic (and controlled international) market simply had no value once the price shifts revalued the capital. This has the implication that after large price shocks different vintages of investment will have different impacts on output, that is, investments that were undertaken as one set of relative prices will produce less output at those relative prices than newer investments (see below). 
example is simply that after investments have been made, shifts in relative prices or technological innovation can either increase or decrease the value of any given capital good. When the price of a commodity falls then the capital stock associated with the production of that commodity also falls. Given the dependence of many economies on natural resources which require large, long-lasting, investments (such as oil, copper, tin, cocoa, coffee, tea) and the large fluctuations in terms of trade, this is empirically important ${ }^{19}$. Similarly, the process of creative destruction involves reductions in the value of existing capital stocks that embody old techniques due to innovation (Jaffee, 1986). Finally, even though private investors equate costs and expected value when investing the private sector often makes (large) mistakes. The private sector will have its share of ex post white elephants.

\section{IIn How big is this revaluation of effect? Micro evidence}

Once the distinction is drawn, the existence of systematic differences between the cost of public investment and the value of public capital seems perfectly obvious. The key question is whether this distinction is conceptually fruitful and empirically important for understanding the differences in economic performance and for informing policy recommendations.

How large an effect on recorded capital stocks are differences in the efficacy of

19 In fact, this may explain the relatively slower growth of the natural resource dependent economies, conditional on their rates of investment (Sachs and Warner, 1996). What looks like slow TFP growth at capital stocks based on investment flows may really be that massive investments made by governments in resource extraction industries turned out to have very low returns. One possible way of getting at this is to examine the evolution of the stock market valuation of the equity of resource based firms as commodity prices shift. Perhaps this could lead to some useful way to estimate the revaluation of capital impact of terms of trade shifts on Zambia's copper mines or Bolivia's tin mines or Cote d'Ivoire's cocoa plants. 
investment? There are several good reasons to believe that the magnitudes are substantial. However, there is little direct evidence. In particular, the difficulty is that most evidence links directly from investment spending to some output measure and does not distinguish amongst the various reasons; not creating capital, creating the wrong capital, and using capital badly. That said, I break the micro evidence into; spectacular anecdotes, very stylized facts, and thought experiments.

\section{A) Spectacular anecdotes}

The most fun, but least satisfying, evidence comes from journalistic (and first hand development practitioner) accounts. First, there are herds of white elephants. A nuclear power plant in the Philippines cost more than 2 billion dollars but was never commissioned. As mentioned in the introduction, there are steel plants in some countries in which billions of dollars have been poured and have yet to produce any steel. The World Bank financed Morogoro Shoe factory in Tanzania cost $\$ 40$ million but is now a mostly worthless hulk, whose peak capacity utilization was never more than 4 percent (World Bank, 1991). Since in many small, poor countries these large investments are a substantial fraction of total investment, these anecdotes add up. Second, there even more spectacular but less substantiated reports in which the estimated fortunes of countries leaders and their cronies derived from siphoning off, in one form or another, investment funds that are a significant fraction of the country's total investment.

B) An eclectic collection of verz stylized facts

A first piece of evidence about differential public sector effectiveness is the data on ex 
post economic rates of return on World Bank investment projects by country ${ }^{20}$. Table 2 lists the summary statistics and some examples. In an African country the World Bank invested nearly a billion dollars in 31 projects and achieved a median rate of return of 0 (that's zero)! In contrast the 8.2 billion invested in one East Asia country earned a median return of 19.5 percent. The mean return (of countries with nine or more projects) was 14.1 , but with a standard deviation of 4.2 and a range from 0 to 25 . While this evidence cannot distinguish the causes of the differences in returns, there are clearly huge differences in the efficacy of governments in implementing World Bank financed projects.

Table 2: Economic rates of return on government investment projects financed by the World Bank.

\begin{tabular}{|l|l|l|l|}
\hline & $\begin{array}{l}\text { Number of } \\
\text { projects }\end{array}$ & $\begin{array}{l}\text { Cumulative } \\
\text { investment } \\
\text { (millions) }\end{array}$ & $\begin{array}{l}\text { Median ex post } \\
\text { economic rate of } \\
\text { return }\end{array}$ \\
\hline An African country & 31 & 915 & 0 \\
\hline A South Asian country & 88 & 19,718 & 16.5 \\
\hline An East Asian country & 41 & 8.233 & 19.5 \\
\hline All countries & & & 14.1 \\
\hline Source: OED database. & & \\
\hline
\end{tabular}

While this clearly shows differentials in the efficacy of government investments, it does not distinguish costs particularly. What would be wonderful is data on the actual costs on comparable capital goods across countries. That we don't have. Table 3 reports the dollar

${ }^{20}$ The ex post means it is after disbursement of the World Bank loan. Also, these are economic, not financial returns to investment, so that they do value non-marketed outputs, e.g. roads. 
cost per kilometer of similar road construction (in 1985\$) in various countries as taken from various World Bank project documents. While some large fraction of the differences in costs is likely accounted for by technical differences (like the location of the road) it is hard to believe these differences in cost do not at all reflect differences in government effectiveness.

On the other hand, these particular differences are an embrassement of riches as they seem too large and too random to entirely be due to differences in government efficacy.

\begin{tabular}{|l|l|}
\hline \multicolumn{2}{|c|}{$\begin{array}{c}\text { Table 3: of construction of a kilometer of similar } \\
\text { road in selected countries (in 1985S) }\end{array}$} \\
\hline Country & Cost \\
\hline High cost countries & 771,068 \\
\hline Honduras & 721,160 \\
Ethiopia & 631,965 \\
Guatemala & 540,632 \\
El Salvador & 434,650 \\
Pakistan & 426,839 \\
Nigeria & \\
\hline Low cost countries & 143840 \\
\hline Chile & 143306 \\
India & 131966 \\
Costa Rica & 111343 \\
Philippines & 95440 \\
Uruguay & 92072 \\
Korea & 65277 \\
\hline Sri Lanka & 287350 \\
\hline Average & \\
\hline Source: Canning and Fay, 1995. \\
Notes: Brazil and Argentina were not included in the high \\
and low list because of doubts about appropriate deflation \\
and exchange rate conversion under hyperinflation.
\end{tabular}

A third piece of evidence, limited to a single country, is the difference in returns to 
investments in manufacturing in the public versus private sector in India. Rajaiah (1989) compares the returns on capital employed in private and public enterprises and finds that over the $1967 / 68$ to $1973 / 74$ period for which comparable data are available, the returns are 4.2 in the public and 24.9 in the private sector. Even if one limits attention to the goods producing public sector firms to account for the possibly non-commercial nature of many firms, the average return on capital employed is still 3.9. Joshi and Little (1994) use an alternative, indirect, calculation using the relationship between growth rates, investment rates, and capital shares to calculate the returns to investment in some sectors in India over the periods 1960 1975 and 1976-1986. As shown in table 4, they find the return to investment in public sector manufacturing in the latter period was 5.2 percent while the return in private sector manufacturing was more than four times higher, at 22.6 percent. Again, this evidence does not distinguish amongst the multiple reasons why public enterprise profits were lower per dollar of investment. 


\begin{tabular}{|c|c|c|c|c|c|c|c|}
\hline \multirow[t]{2}{*}{ Table 4: } & \multicolumn{7}{|c|}{$\begin{array}{l}\text { Alternative calculations of the returns to investment in public and private } \\
\text { sectors in India. }\end{array}$} \\
\hline & \multicolumn{3}{|c|}{$\begin{array}{l}\text { Return on capital employed from } \\
\text { firm accounts }\end{array}$} & \multicolumn{4}{|c|}{ Inferred from contribution to growth } \\
\hline \multirow{2}{*}{ Period: } & \multirow{2}{*}{$\begin{array}{l}\text { Goods } \\
\text { producing } \\
\text { public } \\
\text { enterprises }\end{array}$} & \multirow{2}{*}{$\begin{array}{l}\text { Private } \\
\text { sector }\end{array}$} & \multirow{2}{*}{$\begin{array}{l}\text { Ratio } \\
\text { Private/ } \\
\text { Public }\end{array}$} & \multirow{2}{*}{$\begin{array}{l}\text { Whole } \\
\text { public } \\
\text { sector }\end{array}$} & \multicolumn{3}{|c|}{ Manufacturing } \\
\hline & & & & & Public & Private & $\begin{array}{l}\text { Ratio } \\
\text { private } \\
\text { /public }\end{array}$ \\
\hline $\begin{array}{l}1960 \text { s and } \\
70 \text { s }\end{array}$ & 3.9 & 24.9 & 6.4 & 5.4 & 2.1 & 11.1 & 5.3 \\
\hline $1976-86$ & & & & 6.2 & 5.2 & 22.6 & 4.3 \\
\hline
\end{tabular}

\section{C) A thought experiment}

The closest counter-part to the perpetual inventory capital stock at the firm level is the inflation adjusted, economically depreciated, cumulative investments in the firm. Imagine what most public enterprises producing private goods in a competitive environment in most developing countries would (and do) sell for relative to cumulated investment ${ }^{21}$. This is the critical thought experiment for distinguishing the "no capital" from the "badly used capital" explanations of the low output from public investments. That is, if the reason for low output from publicly operated capital is the difference between the constrained value of capital (when

21 The two qualifications are important: "private good" so that prices really could be charged and "competitive environment" because many of the most lucrative privatizations are those that sell monopolies, like telecommunications firms where the price paid for accumulated assets is difficult to disentangle from the price paid for the exclusive franchise. 
operated ineffectively) and the market value (when operated well) then public firms should sell for more than their current profit stream. If, on the other hand, the investment spending has not lead to valued assets then the private sector will not pay anything like book value for the firms.

Surprisingly in spite of the spate of privatizations, this remains a thought experiment as I have not been able to collect any information of this type ${ }^{22}$. Boycko, Shleifer and Vishny (1993) do report on the value of privatized Russian firms, which they find to be extraordinarily low, so low that they do not believe the then prevailing prices are good indications of future profit streams ${ }^{23}$. In East Germany the net take from privatizing was negative $\$ 200$ billion, partly because the assets just were not worth much but primarily beacause the new owners had to agree restrictions on labor (this was a "constrained" not "market" value of capital).

${ }^{22}$ I suppose if is naive to be surprised, as for governments to admit they are selling firms for a fraction of what they paid for them is obviously embarrassing and hence best left unstated.

${ }^{23}$ They that at the value of transactions (and exchange rates) of June 1993 the implied value of the entire Russian capital stock was only $\$ 10$ billion, slightly smaller than the asset value of Anheuser-Busch and slightly larger than the Sara Lee corporation. They argue this is primarily not because the assets will not produce a profit stream but because shareholders will be squeezed out of the profits by stakeholders (e.g. managers and workers). 


\section{IV) How big is this effect? Macroeconomic evidence}

A second way of documenting the discrepancy is to look at the impact of capital accumulation on growth rates. I will do so with two methods.

\section{A) Growth factor accumulation and TEP}

Since the distinction between cost of investment and value of capital, while not unobservable in principle, is unobservable in practice for any largish sample of countries, I propose instead to work backwards from known data and, by imposing a series of incredible assumptions, infer the possible magnitude of this effect.

Assume that the evolution of output per worker follows an augmented Solow production function. Then with all the usual algebra one can express the growth rate of output per worker as the growth of physical capital per worker, human capital per worker and define the unexplained portion of output growth, which is the growth of the scale factor on the production function, as TFP ${ }^{24}$. How to interpret TFP is the subject of enormous controversy. Sometimes TFP is simply "the residual" or "a measure of our ignorance." Another interpretation is that the growth of the scale factor on the production function roughly represents the expansion in the stock of available technical knowledge. Since measured TFP in OECD countries is around .5 to 1 percent annum and everyday observation indicates a

${ }^{24}$ See Bosworth, Collins, and Chen (1995) for an excellent discussion and implementation of the various issues involved in this type of "growth accounting" estimate of TFP. The regional pattern of their preferred TFP estimates (in spite of the different data, regional coverage, and time period) are similar to the TFP reported in table 5, SSA -.7, MENA -.4, LAC .1, OECD 1.0, East Asia .8, South Asia .7. 
substantial amount of technological progress the "stock of knowledge" interpretation of TFP, while not necessarily compelling, is not obviously false.

However, in developing countries, fifty-five percent of countries have measured TFP less than zero, with more than a quarter showing TFP as low as negative one percent per annum. This strains the interpretation of the change in the production function scale factor as the change in the stock of productive knowledge. These economies are not forgetting one percent of the stock of knowledge per year. I would argue a more plausible interpretation is that the growth of the capital stock in calculating TFP is overstated because of the variety of investment cost versus value of capital effects discussed above ${ }^{25}$. This suggests a calculation to estimate the magnitude of the deviation of actual creation of the value of productive capital and capital valued at cost of investment.

* First, calculate the growth of TFP country by country using reasonable shares for physical and human capital (since the calculation is obviously crucial but I do not want to bog down in the details, they are in appendix 1).

* Second, assume that "true" TFP growth available to any given economy in the world is the same, fixed number. I use either zero (an obvious lower bound) or one percent per annum (the average in the OECD). This assumption about TFP will in some cases be inconsistent with the observed factor accumulation.

${ }^{25}$ Delong and Summers (1991) emphasize differences across countries in the price of investment goods as an important source of mis-measurement of capital stocks. If prices are higher in India than in Korea then a greater investment rate (in nominal terms) is required to produce an equivalent increment to the real capital stock. The capital stocks used in the base case are calculated with investment rates that use the investment deflation based on international comparisons of prices so this effect is already incorporated. 
* Third, I scale back the rate of factor accumulation to be consistent with the observed rate of growth of output per worker and the assumed TFP. This creates an estimate of factor accumulation I call the "implied" rate of factor accumulation.

In equations the implied rate of factor accumulation $(\hat{k})$ is:

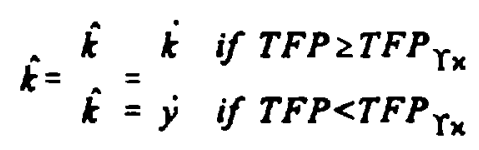

I carry out three variants on this calculation using each of the two assumptions about minimum TFP. The first scales back both physical and human capital, the second scales back just the rate of growth physical capital (even when human capital is still used in calculating TFP) and the third assumes away human capital entirely.

The results of this calculation when all factor accumulation is used in creating TFP and then scaled back are reported in table 5. The results are striking in a number of ways. First, the results suggest that in many regions the "implied" rate of factor accumulation was very very much slower than the standard cumulated investment capital stocks would suggest. In every developing region (except for East Asia) the implied rate of factor accumulation was only half to three quarters as large as the observed rate even when TFP (in the sense of "available" technical progress) was assumed to be zero.

Second, the results are striking in that they accord with my rough intuition of the magnitude of the effectiveness of public investment. In the OECD and the High Performing 
Asian Economies (HPAE) there is very little evidence of deviations of actual from implied factor accumulation. Moreover, the problem appears to be worse in precisely those regions where one suspected: the Middle East, (where governments invested huge oil reflows combined with a subsequent terms of trade shock), Sub-Saharan Africa, and South Asia. In order to know if the pattern of differences by country roughly accords with your own notions of look in appendix 2 for the country by country results.

Third, there is no relationship between the magnitude of actual investments and the ratio of implied to actual growth. The correlation across countries is only -.19 . Africa, for instance, both had low investments and translated only a small fraction of that investment into capital. The MENA region on the other hand had capital accumulation as estimated by cumulated investments growth nearly as large as in the HPAE, but growth of "implied" capital was quite slow. This suggests the effectiveness with which investments create capital is potentially as important in determining growth as the magnitude of investments itself.

\begin{tabular}{|c|c|c|c|c|c|c|}
\hline \multirow{2}{*}{$\begin{array}{l}\text { Region } \\
\text { (number of countries) }\end{array}$} & \multirow{2}{*}{$\begin{array}{c}\text { observed } \\
\text { factor } \\
\text { accumulation }\end{array}$} & \multirow{2}{*}{$\begin{array}{c}\text { "observed" } \\
\text { TFP }\end{array}$} & \multicolumn{2}{|c|}{ if $T F P=0$} & \multicolumn{2}{|c|}{ if $T F P=1 \%$ p.a. } \\
\hline & & & Implied & $\begin{array}{l}\text { Implied } \\
\text { /Observed }\end{array}$ & Implied & $\begin{array}{l}\text { Implied } \\
\text { /Observed }\end{array}$ \\
\hline Middle East, North Africa (9) & 3.53 & -1.3 & 1.62 & $100.0 \%$ & 0.95 & $26.9 \%$ \\
\hline Sub-Saharan Africa (21) & 2.03 & -0.6 & 0.99 & $48.8 \%$ & 0.17 & $8.4 \%$ \\
\hline South Asia (6) & 2.13 & -0.9 & 1.15 & $54.0 \%$ & 0.19 & $8.9 \%$ \\
\hline $\begin{array}{l}\text { Latin America and Caribbean } \\
\text { (23) }\end{array}$ & 1.69 & -0.1 & 1.22 & $72.2 \%$ & 0.41 & $24.3 \%$ \\
\hline $\begin{array}{l}\text { High Performing Asian } \\
\text { Economies (7) } \\
\end{array}$ & 3.84 & 1.2 & 3.63 & $94.5 \%$ & 3.07 & $79.9 \%$ \\
\hline Other Asian Economies (4) & 1.64 & 0.3 & 1.56 & $95.1 \%$ & 0.82 & $50.0 \%$ \\
\hline OECD (24) & 1.79 & 1 & 1.75 & $97.8 \%$ & 1.32 & $73.7 \%$ \\
\hline Sonirce & & & & & & \\
\hline
\end{tabular}


Other variants on this calculation obviously give different results, but the flavor of the results persists. If one scales back just physical capital while keeping human capital in the TFP calculation, the results are even more dramatic, with regions like MENA, SSA and South Asia showing zero growth contribution of physical capital accumulation over the period. On the other hand, if one assumes that human capital had no effect on output and hence use only physical capital in creating TFP and then scales back just the physical capital, the results are obviously less dramatic as fewer countries have negative TFP.

\begin{tabular}{|c|c|c|c|c|c|c|c|}
\hline \multirow[t]{3}{*}{ Region } & \multirow[t]{3}{*}{$\begin{array}{r}\text { of } \\
\text { countries }\end{array}$} & \multicolumn{3}{|c|}{$\begin{array}{c}\text { Adjustment of just the physical capital } \\
\text { stock with educational capital in the } \\
\text { TFP calculation }\end{array}$} & \multicolumn{3}{|c|}{$\begin{array}{r}\text { Adjustment of just physical capital } \\
\text { without education capital in the TFP } \\
\text { calculation }\end{array}$} \\
\hline & & \multicolumn{2}{|c|}{$\begin{array}{l}\text { Percent per annum } \\
\text { growth }\end{array}$} & \multirow[t]{2}{*}{$\begin{array}{l}\text { Implied } \\
\text { IObserved }\end{array}$} & \multicolumn{2}{|c|}{$\begin{array}{l}\text { Percent per annum } \\
\text { growth }\end{array}$} & \multirow[t]{2}{*}{$\begin{array}{l}\text { Implied } \\
\text { IObserved }\end{array}$} \\
\hline & & Observed & Implied & & Observed & Implied & \\
\hline $\begin{array}{l}\text { Middle East, North } \\
\text { Africa }\end{array}$ & 9 & 1.9 & 0 & $0.0 \%$ & 1.58 & 0.5 & $36.7 \%$ \\
\hline Sub-Saharan Africa & 21 & 0.85 & -0.19 & Negative & 0.7 & 0.45 & $64.2 \%$ \\
\hline South Asia & 6 & 0.92 & -0.05 & Negative & 0.76 & 0.73 & $96.0 \%$ \\
\hline $\begin{array}{l}\text { Latin America and } \\
\text { Caribbean }\end{array}$ & 23 & 1.08 & 0.61 & $56.5 \%$ & 0.89 & 0.7 & $78.6 \%$ \\
\hline $\begin{array}{l}\text { High Performing Asian } \\
\text { Economies }\end{array}$ & 7 & 3.03 & 2.82 & $93.1 \%$ & 2.5 & 2.5 & $100.0 \%$ \\
\hline Other Asian Economies & 4) & 1.19 & 1.09 & $91.6 \%$ & 0.98 & 0.98 & $100.0 \%$ \\
\hline OECD & 24 & 1.36 & 1.32 & $97.1 \%$ & 1.12 & 1.11 & $99.1 \%$ \\
\hline
\end{tabular}

This calculation itself is of course not "proof" of the mis-measurement of capital stock growth, it simply states the implications of reversing the interpretation of slow growth from "low TFP in spite of capital accumulation" to "mismeasured capital accumulation." In spite of the fact that nearly all previous TFP calculations have taken perpetual inventory capital stocks at face value, there is no logical or theoretical grounds on which to insist that the capital 
stock estimates are correct. This is particularly the case for the public sector.

Correlations with some indicator of "government" or "policy" performance might be helpful in distinguishing amongst interpretations of the data. Recently Sachs and Warner (1995) have proposed an indicator of overall policy that combines a binary indicator of whether or not a government is repressive and a binary indicator of a minimum amount of "openness" and those non-repressive and open governments are classified as having an acceptable policy environment. Table 7 shows the difference in the observed versus implied capital stock growth by whether or not regimes were politically repressive. The average observed rate of growth of the capital stock was almost identical between the two sets. However, the "implied" rate of factor accumulation is 86 percent of the observed for the politically non-repressive economies but only 50 percent for the repressive governments. Moreover, not only is the difference between observed and "implied" lower but the variance of the difference is much higher for repressive regimes ${ }^{26}$. So while some repressive regimes might be effective at creating capital, others are very very ineffective. The evidence is suggestive that the problem of low returns on investment is related to issues of governance, in the broad sense of government efficacy, not just economic policy.

26 The difference between repressive and non-repressive is robust whether one excludes Africa (mostly classified as repressive) or the OECD (non-repressive) from the calculations. 


\begin{tabular}{|l|r|r|r|r|r|}
\hline Table 7: & $\begin{array}{l}\text { Ratio of observed to implied factor accumulation, across types of } \\
\text { countries. }\end{array}$ \\
\hline \begin{tabular}{l|r|r|r|r|} 
Country \\
classification
\end{tabular} & $\begin{array}{r}\text { \# of } \\
\text { countries }\end{array}$ & $\begin{array}{r}\text { Percent per annum growth } \\
\text { factor accumulation }\end{array}$ & Observed & Implied & $\begin{array}{r}\text { Standard } \\
\text { deviation of } \\
\text { the } \\
\text { difference }\end{array}$ \\
\cline { 1 - 5 } $\begin{array}{l}\text { Non- } \\
\text { repressive }\end{array}$ & 56 & 2.14 & 1.84 & $86.0 \%$ & 0.69 \\
\hline Repressive & 38 & 2.18 & 1.08 & $49.5 \%$ & 1.9 \\
\hline & 28 & 2.27 & 2.15 & $94.7 \%$ & 0.46 \\
\hline $\begin{array}{l}\text { Acceptable } \\
\text { policies }\end{array}$ & 66 & 2.1 & 1.27 & $60.5 \%$ & 1.56 \\
\hline Bad policies & & & & & \\
\hline Sources: Sachs and Warner, 1995 for classification of countries.
\end{tabular}

\section{B) Results of growth regressions}

The second way to illustrate the implications of assuming capital is mismeasured at the macroeconomic level is to estimate a growth model that distinguishes private from public investment. We specify two typical growth regressions, one of which is a simple growth accounting exercise that regresses growth on (potentially endogenous) investment rates and another of which combines investment variables with other, policy control variables. (The full regressions are reported in appendix 3$)^{27}$.

${ }^{27}$ Hulten (1996) does similar regressions within the context of a extended Solow model in which the coefficients on public and private investment are treated as production function parameters. 


\begin{tabular}{|c|c|c|c|c|}
\hline \multirow[t]{3}{*}{ Table 8: } & $\begin{array}{l}\text { on based } \\
\text { nt. }\end{array}$ & mates of the & ve return & ate and \\
\hline & \multicolumn{2}{|c|}{ Without policy controls } & \multicolumn{2}{|c|}{ With policy controls } \\
\hline & Private & Public & Private & Public \\
\hline $\begin{array}{l}\text { Coefficient } \\
\text { (t-statistic) }\end{array}$ & $\begin{array}{l}.223 \\
(6.41)\end{array}$ & $\begin{array}{l}.115 \\
(2.82)\end{array}$ & $\begin{array}{l}.222 \\
(6.29) \\
\end{array}$ & $\begin{array}{l}.093 \\
(2.09)\end{array}$ \\
\hline Share of GDP & 10.9 & 8.9 & 11.0 & 8.9 \\
\hline $\begin{array}{l}\text { Implied relative } \\
\text { effectiveness of public } \\
\text { investment }\end{array}$ & & $62.5 \%$ & & $51.2 \%$ \\
\hline \multicolumn{5}{|c|}{$\begin{array}{l}\text { Notes: The implied relative effectiveness is the ratio of government investment that passes } \\
\text { into public capital growth if the returns to capital on private and public capital are equal. } \\
\text { The returns are estimated as the growth coefficient divided by the estimated capital-output } \\
\text { ratio for each type of capital, which is the relative investment shares times } 2.5 \text {. }\end{array}$} \\
\hline
\end{tabular}

How is the difference in coefficients of private and public investment to be interpreted? Certainly one possibility is that the productivity of public capital is lower and another interpretation is that the public sector uses its capital less effectively. An equally plausible interpretation is that the impact of public capital on output is large, but that the effect of public investment on public capital is small. If we assume that public capital's share in output is proportional to its share in total investment then we can use the estimated coefficient to infer the average relative effectiveness of public investment. The estimates derived from this approach reported in table 8 , of between 50 and 60 percent. These accord remarkably well with the estimates from the TFP approach when TFP is assumed to be zero. 
VD Relationship to previous literature and policy implications

Since all of the previous literature has relied on either on expenditures or cumulative investment flows this critique leads to fundamentally different interpretations of the results. Rather than drawing inferences from estimates about the effect of public capital (or the optimal effect of any kind of expenditure) as if one were recovering estimates of a "production function" it is equally or more plausible that the results reflect differences in efficacy across countries, especially when countries with extremely different types of governments are included in the same analysis.

\section{A) Empirical literature on government spending and performance}

Growth and government spending. The literature on government spending and growth can be classified into four strands.

One estimates the impact of the level of total government expenditures or government consumption expenditures on growth. Some Ram (1986), Kormendi and Meguire (1985) find higher larger government expenditures associated with higher growth while other studies such as Landau (1986), Barro (1991), and Dowrick (1992) find higher government expenditures associated with lower growth while Levine and Renelt (1992) show that government expenditures is not a robust (partial) correlate of growth. Differences in variable definition and econometric technique appear to account for the differences in results ${ }^{28}$. and more serious

28 The definition of the variable for the government expenditures in the growth regression as either the share of government spending ( $G / Y)$ (generally negative findings) or the growth of government spending $G^{*}(G / Y)$ (generally positive findings) appears to make huge difference. Dowrick (1992) argues that an upward simultaneity bias from higher income growth leading to more government growth accounts for the positive coefficients. 
question is exactly what these estimates of partial correlations between government expenditures and growth performance are actually identifying.

Slemrod (1995) has argued that if all governments are choosing the level of expenditures optimally then the interpretation of the coefficient of level of expenditures on growth is problematic. I am making almost the opposite point. Governments are not choosing either the level of expenditures or their productivity with anything like the same degree of optimality with respect to some growth or welfare related objective function. Governments face very different constraints and there is no reason to expect the impact of public investment to be uniform across countries of different types.

The second strand of the literature examines the impact of the magnitude and composition of government investment spending on growth. Easterly and Rebelo (1993) have four empirical findings relevant to the present paper. First, government investment overall has a very low impact on growth ${ }^{29}$. Second, investment of the central government has a much larger growth impact than investments of public enterprises. This finding is consistent with an observation that the control over public enterprises is even worse than over central government. Third, they find that across sectors, only investment in transport and communications has any growth impact ${ }^{30}$. This finding on the impact of transport is supported by the results of Canning and Fay (1995) who find a strong relationship between physical

29 This confirms the finding by Landau (1986) for the 1960-80 period that government capital expenditures as a share of GDP are not associated with higher growth.

${ }^{30}$ On the other hand Baffes and Shah (1993) find very low output elasticities of "infrastructure capital" from perpetual inventory estimates in a time series trans-log production for 25 countries, but with a large variation across countries. 
stocks of roads and growth ${ }^{31}$. Fourth, they find that it is difficult to identify any negative effect of the level (or structure) of taxation on growth.

The third strand examines the impact of the allocation of government spending (not just investment) on growth ${ }^{32}$. Devarajan, Swaroop and Zhou (1996) find:

All of the standard candidates for productive expenditure--capital, transport and communication, health, and education-- had either a negative or insignificant relationship with economic growth.

These authors recognize the important issue is whether public expenditures increase public capital.

The fourth strand estimates the impact of public capital from time series. If governments differed in the efficacy of their investments one would expect these estimates to be very different for different countries. Unfortunately there are few good estimates of the productivity of public capital and what few there are are of limited comparability ${ }^{33}$. But what studies there are show huge differences across economies, with estimates in Mexico of the return to public capital between 5 and 7 percent (versus 14 to 18 for private capital) (Shah, 1992) while estimates are 77 percent in Taiwan. China and 51 percent in Korea (Uchimura and Gao, 1993).

${ }^{31}$ This points up the possibility of attempting to estimate the efficacy parameter directly by relating changes in physical stocks (e.g. miles of roads) to expenditures.

32 There is another strand which looks at the specific component of government spending: military spending. This literature finds sometimes positive (Landau, 1994) sometimes negative (Knight, Loayza, and Villanueva, 1995) growth effects depending on the specification of the possible non-linearities and the endogeneity of spending to actual threats.

${ }^{33}$ I'll ignore the whole literature in the USA and the debate between Aschauer (1989), who finds returns around 60 percent and Holtz-Eakin (1992) who finds returns around 0. 
Recent results about the growth impact of concessional assistance are also relevant. If aid finances government projects and particularly does so in climates in which government investment is not particularly productive, then a finding an impact of aid financing on growth not significantly different from zero is not particularly surprising (even if it were to expand aggregate government investment) ${ }^{34}$.

Sectoral outcomes and spending. In addition to the growth literature, many have examined the impact of expenditures in the education and health sectors on outcomes in those sectors. Generally, after controlling for the overall level of income, there is no evidence of an impact of government spending. In health, Murray, Govindaraj, and Musgrove (1994) find no link between life expectancy and the fraction of GDP spent on health care ${ }^{3 s}$. In education, there is no link between educational spending per pupil and comparisons on internationally comparable examinations (Elley, 1992). Neither Landau (1986) and Hanushek (1996) find any connection between educational spending and economic growth.

All of the typically negative or ambivalent findings on government investment (or spending) are potentially a reflection of differences in investment efficacy. One cannot conclude from the fact that educational expenditures may fail to have the expected magnitude (and even perhaps to even be statistically insignificant) that increased education does not raise

${ }^{34}$ This is different from the rationale presented in Boone (1994), which is that aid financing does not expand investment.

${ }^{33}$ Anand and Ravallion (1993) do find a positive effect, but in a very limited sample of 22 quite poor countries. The very high correlation of GDP per capita and "Public Health Spending Per Person" in their data of 91 makes the separate identification of the two effects problematic in both cases. 
output. The regression only tells the output impact of additional expenditures at the average efficacy of the sample.

\section{B) Giving sensible policy advice}

The main policy implication is that in order to give sensible advice about government investments we need country specific information. In contemplating a recommendation for government investment something like the decision tree in figure 1 might be helpful (although this is highly stylized). There are three main points from the figure. First, policy recommendations will be country specific. Recommending that Chile not build roads because Tanzania's experience was disastrous is as wrong as its opposite.

Second, most of the answers necessary for policy making are primarily analytical and only secondarily empirical. We need to know on analytical grounds what is the desirable scope for government action ${ }^{36}$. The empirically observed returns to public enterprises are not the crucial feature, the question is how the economy would have performed in the absence of the public enterprises, which depends on views about the degree of private sector responsiveness. Also, the appropriate incentives for effective public sector supply are an analytic question and the answer will vary from country to country and from sector to sector.

Third, comparisons across countries will have to be very much finer than our current data allow to be useful. Comparing spending on this or that and performance across countries

${ }^{36}$ The private returns to education computed from wage surveys or the "costeffectiveness" of particular medical interventions are as irrelevant to government investment spending as are the returns on the stock market. 
does not help distinuish any of critical branching points for policy recommendations.

\section{Conclusion}

Nearly all of the recent spate of work on the empirics of growth that has investigated the impact of various types of government spending has operated, implicitly or explicitly, under the assumption that the same positive model of government behavior held for all countries. While this may be a reasonable assumption for countries with similar economic and political structures, it is obviously false in general. This implies that inferences about the impact of government spending from a group of countries to a specific country or from one country to another are invalid.

This paper has presented empirical results which suggest this distinction has important implications not only for our understanding of the existing literature but also for policy advice. The fact that government investments of various types may or may not be associated with economic performance is an interesting fact but by itself provides little useful information for policy recommendations to particular countries. Instead there is an entirely different set of questions for policy, that intrinsically depend on assessments of the capacity of the governments and private sectors as well as an assessment of the analytical and empirical grounds for public intervention. 


\section{Bibliography}

Anand, Sudhir and Martin Ravallion, 1993, "Human Development in Poor Countrie: On the Role of Private Incomes and Public Services," Journal of Economic Perspectives 7(1) pp 133-150.

Aschauer, David, 1989, “Is public expenditure productive?” Journal of Monetary Economics 23: 177-200.

Baffes, John and Anwar Shah, 1993, "Productivity of public spending, sectoral allocation choices and economic growth," World Bank Policy Research Working Papers \#1178 (September).

Barro, Robert J., 1991, "Economic Growth in a Cross Section of Countries," Quarterly Journal of Economics, 106(2):407-446.

Boskin, Michael J., Marc Robinson and John M. Roberts, 1985, “New Estimtate of government tangible capital and net investment," NBER Working Paper Series \#1774.

Bosworth, Barry, Susan Collins, and Yu-chin Chen, 1995, "Accounting for differences in Economic Growth," mimeo (Brookings).

Boycko, Maxim, Andrei Shliefer, and Robert Vishny, 1993, "Privatizing Russia," Brookings Papers on Economic Activity, 2 pp 139-192.

Canning David and Marianne Fay, "Infrastructure and growth." mimeo.

Campos, Edgardo and Hilton Root, 1996, East Asia, Brookings: Washington DC.

De Long, J. Bradford and Lawrence H. Summers, 1992. "Equipment investment and economic growth: how strong is the nexus?" Brookings Papers on Economic Activity, 2:157-211.

Easterly William and Sergio Rebelo, 1993, "Fiscal Policy and Economic Growth: An Empirical Investigation," Journal of Monetary Economics, 32.

Elley, Warwick B., 1992, How in the world de students read? : IEA study of reading literacy, Hamburg : The International Association for the Evaluation of Educational Achievement,

Devarajan Shanta, Vinaya Swaroop, and Heng-fu Zhou, 1996, "The composition of public expenditure and economic growth," forthcoming Journal of Monetary Economics. 
Hanushek, Eric A., 1996, "Schooling, labor force quality, and economic growth," NBER Working Paper Series No. 5399 (January)..

Hayek, Freidrich A., 1941, The Pure Theory of Capital, Chicago: University of Chicago Press.

Hirschmann, Albert, 1970, Exit Yoice, and Loyalty: responses to decline in fims. organizations, and states, Cambridge, Mass: Harvard University Press.

Holtz-Eakin, Douglas, 1992, "Public Sector Capital and the Productivity Puzzle," NBER Working Paper \#4122.

Hulten, Charles, 1996, "Infrastructure and economic development: Once more into the breach," mimeo.

Isham, Jonathan, Deepa Narayan, and Lant Pritchett, 1995, "Does Participation Improve Performance? Establishing Causality with Subjective Data," World BankEconomic Review, 9(2), pp175-201.

Isham, Jonathan, Daniel Kaufmann, and Lant Pritchett, 1996, "Governance and the Returns to Investment: An Empirical Investigation," World Bank Policy Research Paper 1550.

Jaffee, Adam, 1986, "Technological Opportunity and Spillovers of R\&D: Evidence from Firms' Patents, Profits, and Market Value," American Economic Review 76(5):9841001.

Joshi, Vijay and I.M.D. Little, 1994, India: Macroeconomics and Political Economy 19641991. Washington DC: World Bank.

Knight, Malcolm, Norman Loayza, and Daniel Villanueva, 1996, "The peace dividend: military spending cuts and economic growth," International Monetary Fund Staff Papers, 43:1-37.

Kormendi, Roger and Philip Meguire, 1985, “Macroeconomic determinants of growth; cross-country evidence," Journal of Monetary Economics 16:141-163.

Landau, Daniel, 1986, "Government and Economic Growth in the Less Developed Countries: An Empirical Study," Economic Development and Cultural Change, 35:35-75.

Landau, Daniel, 1994, "Impact of military expenditures on economic growth in the less developed countries," Defence and Peace Economics, 5(3):205-220.

Levine, Ross and David Renelt, 1992, "Sensitivity analysis of cross- country growth 
regressions," American Economic Review, 82:942-963.

Murray, Christopher, R. Govindaraj, and Philip Musgrove, 1994, "National Health Expenditures: A Global Analysis," in Global Comparative Assessments in the Health Sector: Disease Burden. Expendtireus and Intervention Packages, WHO:Geneva.

Obsborne, David and Ted Gaebler, 1992, Reinventing Government, New York: Plume.

Olson, Mancur, 1996, "Big Bills Left on the Sidewalk: Why Some Nations are Rich and Others Poor," Journal of Economic Perspectives, 10(2):3-24.

Ostrom, Elinor, 1995, "Incentives, Rules of the Game, and Development," Annual Bank Conference on Development Economics 1995.

Rajaiah, B., 1989, Returns to investment and Efficiency in Public Enterprises in India, Delhi: Mittal Publications.

Ram, Rati, 1986, "Government Size and Economic Growth: A new Framework and Some Evidence from Cross-Section and Time-Series Data," American Economic Review, 76(1):191-203.

Sachs, Jeffrey and Andew Warner, 1995, "Economic reform and the process of global integration," Brookings Papers on Economic Activity, 1:1-118.

Shah, Anwar, 1992, "Dynamics of public infrastructure, indsutrial productivity, and profitability," Review of Economics and Statistics, 74(1): 28-36.

Slemrod, Joel, 1995, "What do cross-country studies teach about government involvement, prosperity, and economic growth?” Brookings Papers on Economic Activity, 2:373-431.

Uchimura, Kauko and Jong Gao, 1993, "The importance of infrastructure on economoic development," World Bank, Latin American Regional Office, Washington DC.

World Bank, 1991, World Development Report 1991, Washington DC: Oxford University Press for the World Bank. 
Appendix 1: Calculation of observed factor accumulation, TFP, and implied.

Equations. The formulas are quite simple, one begins with a Cobb-Douglas production function in labor, physical capital and human capital with a scale factor that implies neutral technical progress.

$$
Y_{t}=A(t) * K_{1}^{\alpha_{i}} * H_{1}^{\alpha_{h}} * L_{t}^{\alpha_{t}}
$$

Impose constant returns to scale, so that

$$
\alpha_{k}+\alpha_{h}+\alpha_{l}=1
$$

Normalize to the growth of output per worker and take logs and differentiate with respect to time and the following equation is a definition of TFP:

$$
\dot{y}=\alpha_{k} * \dot{k}+\alpha_{1} * \dot{h}+T F P
$$

where lower case with dots is the percentage rate of change of per worker quantities. All of the calculations are done with the per annum rate of change estimated with a least squares trend over the entire period of data availability (generally 1960 to the late 1980s).

Data. To empirically implement the above equation one needs data on the four items that enter the equation, GDP, physical capital stock, human capital stock, and labor force. For each of those quantities I have two data sources, which are described in the table below. All of the results in the paper, unless otherwise specified are based on the set of data in the first column (Summers-Heston, King-Levine, Barro-Lee) but all calculations were also performed using the set in the second column (World Bank, Nehru-Dhareshwar, NehruSwanson-Dubey), with roughly similar results overall. The correlation between the two TFP growth rate series is .77 . 


\begin{tabular}{|l|l|l|}
\hline Appendix table A1.1: & Description of data sources for TFP calculations \\
\hline Variable & $\begin{array}{l}\text { Data collection I: Summers- } \\
\text { Heston, King-Levine, Barro-Lee. }\end{array}$ & $\begin{array}{l}\text { Data collection II: World Bank, } \\
\text { Nehru-Dharesewar, Nehru- } \\
\text { Swanson-Dubey. }\end{array}$ \\
\hline GDP & $\begin{array}{l}\text { Source: Summers and Heston, } \\
\text { 1991, Penn World Tables, Mark 5 }\end{array}$ & Source: World Bank data \\
\cline { 2 - 4 } & $\begin{array}{l}\text { Description: Real GDP } \\
\text { (RGDPCH) expressed in } \\
\text { purchasing power equivalents. }\end{array}$ & $\begin{array}{l}\text { Description: Real GDP in local } \\
\text { currency, constant prices. }\end{array}$ \\
\hline Labor Force & Penn World Tables, Mark 5 & Penn World Tables, Mark 5 \\
\hline Stocks & \begin{tabular}{l} 
Source: King and Levine (1994) \\
\cline { 2 - 4 }
\end{tabular} & $\begin{array}{l}\text { Sapirce: Nehru and Dhareshewar } \\
\text { (1993) }\end{array}$ \\
\hline $\begin{array}{l}\text { Capital stock series in P\$ based on } \\
\text { of the investment rates in the } \\
\text { PWT5 from an estimate of the } \\
\text { initial capital stock in 1960. }\end{array}$ & $\begin{array}{l}\text { Capital stock series in constant } \\
\text { US\$ based on a perpetual } \\
\text { inventory cumulation of } \\
\text { investment rates in the World } \\
\text { Bank National Accounts data. }\end{array}$ \\
\hline Human Capital & $\begin{array}{l}\text { Source: Barro and Lee 1993 and } \\
\text { Pritchett, 1996. }\end{array}$ & $\begin{array}{l}\text { Source: Nehru, Swanson, and } \\
\text { Dubey, 1993 and Pritchett 1996. }\end{array}$ \\
\cline { 2 - 3 } $\begin{array}{l}\text { Description: The underlying data } \\
\text { on years of schooling of the adult } \\
\text { population ( }>25 \text { years) are } \\
\text { computed by Barro and Lee based } \\
\text { in Census reports of educational } \\
\text { attainment and enrollment rates. } \\
\text { Pritchett (1996) calculates the } \\
\text { human capital stock based on the } \\
\text { years of schooling from assumed } \\
\text { returns to schooling. }\end{array}$ & $\begin{array}{l}\text { Description: The underlying data } \\
\text { on years of schooling of the } \\
\text { labor force aged population } \\
\text { (>15 years) are computed by N- } \\
\text { S-D based on a perpetual } \\
\text { inventory cumulation of } \\
\text { historical enrollment rates } \\
\text { (adjusted for repetition, drop } \\
\text { out). Pritchett (1996) calculates } \\
\text { the human capital stock based on } \\
\text { the years of schooling from } \\
\text { assumed returns to schooling. }\end{array}$ \\
\hline
\end{tabular}

Parameters. The final items needed for the TFP calculations are the shares of physical and human capital. For the calculations in this paper I assume that the capital share $\alpha_{k}$ is .4, the labor share is .6 and that half the labor return is human capital, so the human capital share 
$\alpha_{h}$ is .3 . I could go into great length justifying these particular values, but any reasonable set of parameters will produce quite similar results, especially in terms of patterns across countries. (There is one point, which is that one of the major implications of this paper is that the regression estimates of these parameters will be biased. In particular, one previous finding of mine is that the regression estimated value of human capital is very near zero (Pritchett, 1996) even though the national accounting value must be somewhere around .3.)

\section{B) Data sets}

This presents the exact same calculations are reported in table 5 in of the text using completely different data sets. The same basic results come through, especially the low in Africa and Latin America and high in the OECD and HPAE. Similarly, if the cross tab calculations by the political or policy indicators similar results appear with the two datasets.

\begin{tabular}{|c|c|c|c|c|}
\hline \multicolumn{2}{|c|}{ Appendix table A1.2: } & \multicolumn{3}{|c|}{$\begin{array}{l}\text { The same calculations as in table } 5 \text { with another data set } \\
\text { for growth, capital, and education. }\end{array}$} \\
\hline \multirow[t]{3}{*}{ Region } & \multirow[t]{3}{*}{ \# of countries } & \multicolumn{3}{|c|}{$\begin{array}{c}\text { Adjustment of all factor accumulation (Physical and } \\
\text { Human Capital) }\end{array}$} \\
\hline & & \multicolumn{2}{|c|}{ Percent per annum growth } & \multirow{2}{*}{$\begin{array}{l}\text { Implied } \\
\text { /Observed }\end{array}$} \\
\hline & & Observed & Implied & \\
\hline MENA & 9 & 3.47 & 2.43 & $70.0 \%$ \\
\hline SSA & 20 & 2.38 & 0.36 & $15.1 \%$ \\
\hline South Asia & 4 & 1.96 & 1.89 & $96.4 \%$ \\
\hline$\overline{\mathrm{LAC}}$ & 18 & 1.73 & 1.15 & $66.5 \%$ \\
\hline HPAE & 5 & 4.32 & 4.13 & $95.6 \%$ \\
\hline $\begin{array}{l}\text { SE Asia } \\
\text { Pacific }\end{array}$ & 2 & 1.95 & 1.8 & $92.3 \%$ \\
\hline OECD & 23 & 1.71 & 1.68 & $98.2 \%$ \\
\hline
\end{tabular}


Appendix 2: Country by country results, growth. TFP, "implied" factor accumulation

$\begin{array}{ccccc}\text { Name } & \text { Growth of } & \text { TFP } & \text { Actual } & \text { Implied Ratio } \\ \text { GDP } & & \text { Factor } & \text { Factor Implied to } \\ & \text { Per worker } & \text { Accum. } & \text { Accum. Actual }\end{array}$

South Asia

NPL

IND

LKA

BGD

AFG

PAK

$\begin{array}{ll}1.67 & -3.8 t \\ 1.17 & -0.87 \\ 1.07 & -0.7 t \\ 1.07 & -0.37 \\ 0.67 & 0.07 \\ 1.87 & 0.27\end{array}$

other Asia

PHL

PNG

MMR

FJI

$\begin{array}{ll}2.3 t & 0.2 t \\ 1.4 t & 0.0 t \\ 2.27 & 0.6 t \\ 1.4 t & 0.6 t\end{array}$

$-0.48$

$$
0.84
$$$$
-0.58
$$$$
-1.98
$$

0.28

$0.8 \%$

0.28

0.18

1.48

1.58

1.08

1.28

2.14

1.78

2.34

3.38

3.38

1.68

2.98

2.38

3.18

1.98

2.08

1.98

1.47
BRB
Average

PAN

MEX

GTM

sub-Saharan Africa

$\begin{array}{llr}5.4 t & 1.67 & 29.6 t \\ 1.9 t & 1.17 & 57.97 \\ 1.7 t & 1.07 & 58.87 \\ 1.3 t & 1.07 & 76.97 \\ 0.67 & 0.67 & 100.07 \\ 1.67 & 1.67 & 100.08\end{array}$

$\begin{array}{llr}2.1 t & 2.18 & 100.07 \\ 1.5 t & 1.4 t & 93.3 t \\ 1.67 & 1.67 & 100.0 t \\ 0.87 & 0.87 & 100.07\end{array}$

1.98

$1.3469 .2 t$

3.17

1.48

0.08

1.88

$1.4 t$

$0.7 t$

$0.4 t$

1.78

1.78

1.18

1. $3 t$

1.87

1.68

2.38

1.58

2.24

1.18

2.48

1.14

2.28

1.84

1.94

1.38

1.68

\begin{tabular}{|c|c|}
\hline 0.88 & $25.8 \%$ \\
\hline$-0.5 t$ & 0.08 \\
\hline-1.98 & 0.08 \\
\hline 0.27 & 11.18 \\
\hline 0.87 & 57.18 \\
\hline 0.28 & $28.6 t$ \\
\hline $0.1 t$ & 25.08 \\
\hline $1.4 \%$ & 82.48 \\
\hline $1.5 t$ & 88.24 \\
\hline 1.07 & 90.98 \\
\hline 1.28 & 92.34 \\
\hline 1.84 & 100.08 \\
\hline 1.68 & 100.07 \\
\hline $2.3 t$ & 100.08 \\
\hline $1.5 t$ & 100.04 \\
\hline 2.28 & 100.04 \\
\hline $1.1 \%$ & 100.08 \\
\hline 2.47 & 100.08 \\
\hline $1.1 \%$ & $100.0 \%$ \\
\hline $2.2 t$ & 100.08 \\
\hline $1.8 \%$ & $100.0 \%$ \\
\hline 1.98 & 100.08 \\
\hline 1.35 & 100.08 \\
\hline $1.1 \%$ & 72.68 \\
\hline
\end{tabular}

MOZ

$-2.38 \quad-3.78$

1. $3 t$

$-2.34$

0.08 


MLI
ZAR
CAF
TGO
GHA
ZMB
SEN
SLE
UGA
LBR
SWZ
ZAF
LSO
KEN
NER
TZA
MUS
BWA
MWI
ZWE

Average

\begin{tabular}{|c|c|}
\hline 0.87 & $-3.3 t$ \\
\hline $0.1 t$ & $-2.7 t$ \\
\hline 0.38 & -2.68 \\
\hline $2.4 t$ & $-2.6 t$ \\
\hline$-0.6 t$ & -2.07 \\
\hline$-1.5 t$ & $-1.8 t$ \\
\hline$-0.5 t$ & -1.38 \\
\hline 0.98 & -1.28 \\
\hline-0.78 & -1.28 \\
\hline $0.0 t$ & $-0.9 t$ \\
\hline 3.28 & 0.28 \\
\hline 1.87 & 0.47 \\
\hline 6.18 & 2.47 \\
\hline $2.1 t$ & 0.78 \\
\hline 0.47 & 0.44 \\
\hline 2.87 & 1.08 \\
\hline 1.68 & 0.18 \\
\hline 8.07 & 3.18 \\
\hline 1.84 & 0.08 \\
\hline 2.47 & 1.98 \\
\hline .4 & -0.6 \\
\hline
\end{tabular}

MENA
KWT

IRQ

JOR

IRN

ISR

SYR

TUN

DZA

TUR

Average

$\begin{array}{rr}-8.3 t & -10.3 t \\ 2.17 & -3.3 t \\ 3.17 & -1.87 \\ 2.78 & -1.3 t \\ 2.98 & 1.48 \\ 4.7 t & 1.18 \\ 2.98 & 0.18 \\ 4.5 t & 0.87 \\ 3.5 t & 1.07 \\ 3.3 t & -0.37\end{array}$

OECD

NZI

SWE

CAN

USA

PRT

JPN

NLD

DEU

NOR

ESP

FIN

BEL

ISL

MLT

ITA

DNK

\begin{tabular}{|c|c|}
\hline 0.48 & -0.68 \\
\hline 1.68 & $0.6 t$ \\
\hline 1.48 & 0.48 \\
\hline 1.18 & 0.17 \\
\hline 3.48 & 0.78 \\
\hline 5.11 & 2.28 \\
\hline 2.18 & 0.78 \\
\hline $2.5 t$ & 1.38 \\
\hline 2.68 & 0.87 \\
\hline $3.2 \%$ & 1.18 \\
\hline 3.08 & 1.68 \\
\hline 2.48 & 1.18 \\
\hline 2.28 & 1.08 \\
\hline 4.98 & 3.38 \\
\hline 3.67 & 1.98 \\
\hline $1.7 t$ & 0.87 \\
\hline
\end{tabular}

$$
\begin{aligned}
& \text { 4.08 } \\
& 2.87 \\
& 2.84 \\
& 5.0 t \\
& 1.4 t \\
& 0.3 t \\
& 0.88 \\
& 2.14 \\
& 0.57 \\
& 0.94 \\
& \text { 2. } 98 \\
& 1.38 \\
& 3.7 t \\
& 1.48 \\
& 0.08 \\
& 1.88 \\
& 1.5 t \\
& 4.98 \\
& 1.87 \\
& 0.58 \\
& 2.08
\end{aligned}
$$

\begin{tabular}{|c|c|}
\hline-8.38 & 0.07 \\
\hline 2.18 & 38.98 \\
\hline 3.18 & 63.38 \\
\hline 2.74 & $67.5 t$ \\
\hline 1.48 & 100.08 \\
\hline 3.67 & 100.07 \\
\hline 2.88 & 100.07 \\
\hline 3.78 & 100.08 \\
\hline $2.5 t$ & 100.08 \\
\hline .78 & 83.74 \\
\hline
\end{tabular}

\begin{tabular}{|c|c|}
\hline 0.44 & 40.08 \\
\hline 1.08 & $100.0 t$ \\
\hline $1.0 t$ & 100.08 \\
\hline 1.08 & $100.0 t$ \\
\hline 2.74 & 100.04 \\
\hline 2.98 & 100.04 \\
\hline 1.48 & 100.08 \\
\hline 1.28 & $100.0 t$ \\
\hline $1.8 t$ & 100.04 \\
\hline 2.14 & 100.08 \\
\hline 1.48 & 100.08 \\
\hline 1.48 & 100.08 \\
\hline 1.28 & 100.08 \\
\hline 1.68 & 100.08 \\
\hline 1.68 & 100.07 \\
\hline 1.08 & 100.08 \\
\hline
\end{tabular}

$$
\begin{aligned}
& 2.07 \\
& 5.4 t \\
& 4.98 \\
& 4.0 t \\
& 1.4 t \\
& 3.6 t \\
& 2.8 t \\
& 3.7 t \\
& 2.5 t \\
& 3.5 t
\end{aligned}
$$

1.08

1.08

1.08

1.08

2.74

2.94

1.48

1.28

1.87

2.17

1.48

1.48

1.28

$1.6 t$

1.68

1.08

$$
\begin{aligned}
& 0.87 \quad 20.07 \\
& 0.17 \quad 3.68 \\
& 0.38 \quad 10.78 \\
& 2.48 \quad 48.07 \\
& \begin{array}{ll}
-0.68 & 0.08
\end{array} \\
& -1.58 \quad 0.08 \\
& -0.58 \quad 0.08 \\
& 0.98 \quad 42.98 \\
& -0.78 \quad 0.08 \\
& 0.08 \quad 0.08 \\
& \text { 2.97 } 100.07 \\
& 1.3 t \quad 100.08 \\
& 3.78100 .08 \\
& 1.48 \quad 100.08 \\
& 0.08 \quad 0.08 \\
& 1.87 \quad 100.08 \\
& 1.58 \quad 100.08 \\
& 4.98100 .08 \\
& 1.88 \quad 100.08 \\
& 0.57100 .07 \\
& 0.98 \quad 44.87
\end{aligned}
$$


FRA

GBR

AUT

CHE

GRC

AUS

CYP

IRI

Average

HPAE

IDN

HKG

MYS

SGP

THA

KOR

TWN

Average
$2.87 \quad 0.87$

$1.87 \quad 0.68$

$3.47 \quad 0.87$

1.48

4.48

1.68

3.88

2.68

$2.6 t$

0.07

1.78

0.88

2.28

0.98

1.08

4.78

4.78

3.58

4.88

3.78

5.58

5.78

4.78

$-0.8 t$
$2.8 t$
$0.5 t$
$1.8 t$
$1.3 t$
$1.4 t$
$1.7 t$
$1.2 t$

$2.0 t$

1.28

2.57

1.48

2.78

0.84

$1.6 t$

1.78

1.68

5.54

1.98

3.08

3.08

2.47

4.17

4.08

3.48
$2.08 \quad 100.0 \%$

$1.28 \quad 100.08$

2.5t 100.04

$1.48 \quad 100.08$

2.7t 100.08

0.88100 .08

1.67100 .08

1.7t 100.08

$1.6 \% 97.5 t$

4.7 85.5\%

$1.98 \quad 100.08$

3.08100 .08

$3.07 \quad 100.08$

$2.47 \quad 100.07$

4.17100 .08

4.07100 .08

$3.37 \quad 97.9 t$ 
Appendix table 3.1: Growth regressions for investment coefficients

Dependent variable: Per capita growth rate (in percent), World Bank data, decades by decade.

\begin{tabular}{|c|c|c|}
\hline & Without "policy" variables & With "policy" variables \\
\hline Constant & $\begin{array}{l}.33 \\
(.884)\end{array}$ & $\begin{array}{l}3.9 \\
(1.65)\end{array}$ \\
\hline In Initial Income & $\begin{array}{c}-0.42 \\
(1.17)\end{array}$ & $\begin{array}{l}-.82 \\
(2.25)\end{array}$ \\
\hline Private Investment & $\begin{array}{l}22.3 \\
(6.41)\end{array}$ & $\begin{array}{l}22.3 \\
(6.29)\end{array}$ \\
\hline $\begin{array}{l}\text { Consolidated public sector } \\
\text { investment }\end{array}$ & $\begin{array}{l}11.5 \\
(2.82)\end{array}$ & $\begin{array}{l}9.35 \\
(2.09)\end{array}$ \\
\hline Primary Enrollment rate & $\begin{array}{l}-.19 \\
(.20)\end{array}$ & $\begin{array}{l}1.0 \\
(1.03)\end{array}$ \\
\hline Secondary Enrollment rate & $\begin{array}{l}2.0 \\
(1.49)\end{array}$ & $\begin{array}{l}.3 \\
(.203)\end{array}$ \\
\hline Dummy for $1960 \mathrm{~s}$ & $\begin{array}{l}3.1 \\
(5.78)\end{array}$ & \begin{tabular}{|l}
2.49 \\
$(4.32)$
\end{tabular} \\
\hline Dummy for 1970 s & $\begin{array}{l}2.3 \\
(6.08)\end{array}$ & $\begin{array}{l}2.1 \\
(5.97)\end{array}$ \\
\hline Dummy for Sub-Saharan Africa & $\begin{array}{l}-1.2 \\
(2.42)\end{array}$ & $\begin{array}{l}-1.5 \\
(2.90)\end{array}$ \\
\hline Dummy for LAC & $\begin{array}{l}-1.6 \\
(3.54)\end{array}$ & $\begin{array}{l}-1.68 \\
(3.53)\end{array}$ \\
\hline Ratio M2/GDP & & $\begin{array}{l}2.2 \\
(2.01)\end{array}$ \\
\hline Government Consumption/GDP & & $\begin{array}{l}-8.4 \\
(2.41)\end{array}$ \\
\hline $\mathbf{N}$ (obs) & 162 & 136 \\
\hline Adjusted R2 & .485 & .551 \\
\hline
\end{tabular}




Title

WPS1638 Private Pension Funds in Hungary: Early Performance and Regulatory Issues

WPS1639 Income Insecurity and Underemployment in Indonesia's Informal Sector

WPS1640 Labor Regulations and Industrial Relations in Indonesia

WPS1641 Poverty and Inequality During Structural Adjustment in Rural Tanzania

WPS1642 Banking Reform in Transition Countries

WPS1643 The Consequences of Doubling the Minimum Wage: The Case of Indonesia

WPS1644 Pricing Industrial Pollution in China: An Econometric Analysis of the Levy System

WPS1645 How Prices and Macroeconomic Policies Affect Agricultural Supply and the Environment

WPS1646 Budgetary institutions and Expenditure Outcomes: Binding Governments to Fiscal Performance

WPS1647 The Baltics-Banking Crises Observed

WPS1648 The Lender of Last Resort Function Under a Currency Board: The Case of Argentina

WPS1649 Economic Regulation of Water Companies

WPS1650 Bank-Led Restructuring in Poland: An Empirical Look at the Bank Conciliation Process
Author

Dimitri Vittas

Franck Wiebe

Alejandra Cox Edwards

M. Luisa Ferreira

Stijn Claessens

Martin Rama

Hua Wang

David Wheeler

Nlandu Mamingi

Ed Campos

Sanjay Pradhan

Alex Fleming

Lily Chu

Marie-Renée Bakker

Gerard Caprio, Jr.

Michael Dooley

Danny Leipziger

Carl Walsh

Michael Klein

Cheryl W. Gray

Arnold Holle

\section{Date}

August 1996

August 1996

J. Israel

85117

August 1996

August 1996

August 1996

September 1996

September 1996

H. Wang

33255

September 1996

A. Williams 37176

September 1996

September 1996

S. Coffey 32635

September 1996

B. Moore 38526

September 1996

S. Vivas 82809

September 1996 


\section{Policy Research Working Paper Series}

\begin{tabular}{|c|c|c|c|c|}
\hline & Title & Author & Date & $\begin{array}{l}\text { Contact } \\
\text { for paper }\end{array}$ \\
\hline WPS1651 & $\begin{array}{l}\text { Bank-Led Restructuring in Poland: } \\
\text { Bankruptcy and Its Alternatives }\end{array}$ & $\begin{array}{l}\text { Cheryl W. Gray } \\
\text { Arnold Holle }\end{array}$ & September 1996 & $\begin{array}{l}\text { B. Moore } \\
38526\end{array}$ \\
\hline WPS1652 & $\begin{array}{l}\text { Intra-Industry Trade, Foreign Direct } \\
\text { Investment, and the Reorientation } \\
\text { of Eastern European Exports }\end{array}$ & $\begin{array}{l}\text { Bernard Hoekman } \\
\text { Simeon Djankov }\end{array}$ & September 1996 & $\begin{array}{l}\text { F. Hatab } \\
35853\end{array}$ \\
\hline WPS1653 & $\begin{array}{l}\text { Grants and Debt Forgiveness in } \\
\text { Africa: A Descriptive Analysis }\end{array}$ & Leonardo Hernández & September 1996 & $\begin{array}{l}\text { R. Vo } \\
31047\end{array}$ \\
\hline WPS1654 & Indonesia's Palm Oil Subsector & Donald F. Larson & September 1996 & $\begin{array}{l}\text { P. Kokila } \\
33716\end{array}$ \\
\hline WPS1655 & $\begin{array}{l}\text { Uncertainty and the Price for Crude } \\
\text { Oil Reserves }\end{array}$ & $\begin{array}{l}\text { Timothy J. Considine } \\
\text { Donald F. Larson }\end{array}$ & September 1996 & $\begin{array}{l}\text { P. Kokila } \\
33716\end{array}$ \\
\hline WPS1656 & $\begin{array}{l}\text { The Investment Decision: A } \\
\text { Re-Examination of Competing Theories } \\
\text { Using Panel Data }\end{array}$ & Cherian Samuel & September 1996 & $\begin{array}{l}\text { C. Samuel } \\
30802\end{array}$ \\
\hline WPS1657 & $\begin{array}{l}\text { Is There an Optimal Structure for } \\
\text { Decentralized Provision of Roads? }\end{array}$ & $\begin{array}{l}\text { Frannie Humplick } \\
\text { Azadeh Moini-Araghi }\end{array}$ & September 1996 & $\begin{array}{l}\text { J. Williams } \\
82557\end{array}$ \\
\hline WPS1658 & $\begin{array}{l}\text { Decentralizing Structures for } \\
\text { Providing Roads: A Cross-Country } \\
\text { Comparison }\end{array}$ & $\begin{array}{l}\text { Frannie Humplick } \\
\text { Azadeh Moini-Araghi }\end{array}$ & September 1996 & $\begin{array}{l}\text { J. Williams } \\
82557\end{array}$ \\
\hline WPS1659 & $\begin{array}{l}\text { Unemployment Insurance in Algeria: } \\
\text { Implications for a Labor Market in } \\
\text { Transition }\end{array}$ & Elizabeth Ruppert & September 1996 & $\begin{array}{l}\text { H. Osselyn } \\
36039\end{array}$ \\
\hline WPS 1660 & $\begin{array}{l}\text { Mind Your P's and Q's: The Cost of } \\
\text { Public Investment is Not the } \\
\text { Value of Public Capital }\end{array}$ & Lant Pritchett & October 1996 & $\begin{array}{l}\text { S. Fallon } \\
38009\end{array}$ \\
\hline WPS1661 & $\begin{array}{l}\text { Determinants of Public Expenditure } \\
\text { on Infrastructure: Transportation and } \\
\text { Communication }\end{array}$ & $\begin{array}{l}\text { Susan Randolph } \\
\text { Zeljko Bogetic } \\
\text { Dennis Heffley }\end{array}$ & & \\
\hline WPS1662 & $\begin{array}{l}2 \text { From Learning to Partnership: } \\
\text { Multinational Research and } \\
\text { Development Cooperation in } \\
\text { Developing Countries }\end{array}$ & $\begin{array}{l}\text { Giorgio Barba Navaretti } \\
\text { Carlo Carraro }\end{array}$ & October 1996 & $\begin{array}{l}\text { M. Patena } \\
39515\end{array}$ \\
\hline WPS1663 & $\begin{array}{l}3 \text { Internal Finance and Investment: } \\
\text { Another Look }\end{array}$ & Cherian Samuel & October 1996 & $\begin{array}{l}\text { C. Samuel } \\
30802\end{array}$ \\
\hline WPS1664 & Is in Germany & Monika & October 1996 & $\begin{array}{l}\text { H. Arbi } \\
34663\end{array}$ \\
\hline
\end{tabular}

